\title{
Message in a Bottle: Reading from Paper Versus Reading on Screen in ODeL Settings
}

\section{Professor Ignatius GP Gous}

\author{
Department of Biblical and Ancient Studies, University of South Africa \\ gousigp@unisa.ac.za

\section{Dr Jennifer Roberts}

Institute for Open and Distance Learning, University of South Africa

buckjj@unisa.ac.za

\section{Doi:10.5901/mjss.2014.v5n23p2616}

\begin{abstract}
Institutions are moving towards on-screen delivery of tuition, with the implication that students have to read course material onscreen. This necessitates paying attention to the role of student reading skills and linked to this the similarities and differences between reading on paper and reading on-screen. The reasons for moving on-screen are discussed in the context of Open, Distance and e- Learning (ODeL) theories and the role of metacognition in ODeL tuition. In order to contextualise the metacognition of reading attention is given to reading skills in South Africa, to the act of reading itself as it is represented in the brain and mind, as well as to the peculiarities of reading on paper and reading on-screen. An important implication of this overview is that it is not enough to merely present course content to students. The skills to master the content should be taught as well, with the teaching of reading being an integral part thereof. One thing is clear and that is all students and for that matter all readers - whether they read on paper or on-screen, need to be taught meta-cognitive reading strategies.
\end{abstract}

Keywords: Reading skills; On-screen reading; Metacognition; Open, Distance and e-Learning.

\section{Introduction - Messages only in Bottles}

Stories abound of people in days gone by who for whatever reason wanted to get their message from where they are to a distant shore. In the early days they wrote the message on a piece of paper, put it in a bottle and cast it into the ocean, hoping it would reach a reader who was able to respond. Currently messages are once again shipped in glass, as it were; to such an extent that it seems that infants are more comfortable with screens than with paper. In a YouTube video that has gone viral, a one year old "digital native" first swipes an iPad screen, and then attempts the same with the pages of a magazine (Jabr, 2013). When the magazine pages do not respond the way the iPad did, she tests her finger against her leg to see if her finger is still "working". Open Distance Learning (ODL) institutions are beginning to follow the trend by delivering tuition onscreen, requiring their students to read on screens of glass. The question is - will the students get the "bottled" messages?

Technology is driving educational delivery, both in face-to-face and Distance Education settings. It is expected of students to have access to computers and the internet. Information about the course administration such as year books, tutorial letters and assignments is already being delivered predominantly online. Course material is still being offered in a hybrid manner, delivered on paper as well as on screen. However, more and more journals and books are becoming available electronically, and are being accessed and read on screen.

An important reality is that in order to learn, students have to be able to read. Some reading will be done on paper, and more and more reading will be done on screen, thereby interacting with technology. The common denominator is that it requires reading skills to access the information, whether reading from paper or reading on screen.

Another reality relates to technological appropriation versus human development. People who are born into a technological seem to be able to immediately slot into that era, quickly adapting to available technology. They need not reinvent the wheel in order to use the technology available. As human beings, however, each and every person has to walk the full developmental journey in terms of self, skills and maturation. They have to learn from scratch to listen, speak, read, write and perform, in addition to other developmental tasks.

It seems very natural and even intuitive to utilise the newest technologies in every sphere of life, education included. The question is, however, whether people have developed the abilities to use the technology for teaching and 
learning?

This article debates the issue of the role of reading in Distance Education, especially in the light of institutions moving away from on paper to onscreen delivery. In debating the issue, the article touches upon the reasons for moving on screen, as well as the ODL theories behind such moves. On-screen delivery requires on-screen reading, and therefore reading is discussed, touching on reading abilities, the act of reading and the differences between reading on paper and reading on screen. Academic reading requires training and guidance, and therefore the metacognition of reading is touched upon, as well as how reading is and should be taught. All of this is done with the question in mind - are ODL students ready to read on screen? If they do pick up a message in a bottle - will they be able to get the message out of the bottle? It seems they will only be able to do so if they receive continuous support, integrated in the course content delivery.

Breaking the Distance Education "sound barrier" and "reading block" through advanced technology, and thereby giving a voice to educators and students again is a significant step. However, will it make a difference in the success rate of distance education students? Do educators know how to talk in order for students to listen effectively? Do educators know how to communicate effectively with students? Do students know how to listen to lectures and communications and how to read critically whether it be op paper or on glass? Are students prepared to go into the workplace as proficient readers and listeners? Do we have the meta-skills and meta-awareness to enable effective communication? In short: "Do we know how to Read and how to Listen?" Are institutions considering these issues when making policy decisions? Do lecturers take this into account when teaching?

\section{ODL - The Unstoppable Move to On-Screen Teaching and Learning}

According to Sir John Daniel, the former head of the Commonwealth of Learning, Distance Education can be represented through the analogy of the Iron Triangle. He states that the challenge in Distance Education is to increase access, improve quality and cut costs (Daniel, 2013).

When representing access, quality and costs as three vectors, it can be seen how difficult it is to achieve this in a face-to-face, classroom situation. As can be seen in Figure 1, you want to optimise the triangle in order to give more access, better quality and to reduce costs. If you pack more students into the classroom to raise access, you could be accused of damaging the quality. Improving the quality by employing more and better teachers and learning resources and the costs will go up. If you cut the costs for education, you will threaten both access and quality.

Figure 1. The Iron Triangle

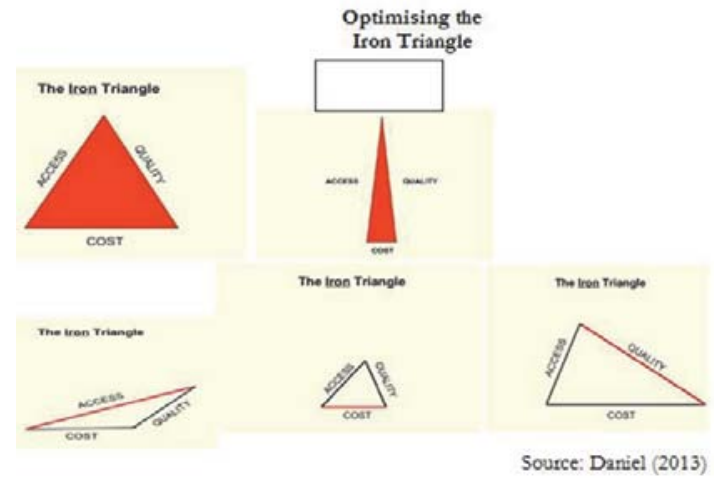

According to Daniel (2013), if you stretch the triangle and achieve, simultaneously, wider access, higher quality and lower costs, you need technology.

The evolution of distance learning shows the emergence of a succession of technologies that helped to offer better education to more people over distance and time at a reasonable cost. By looking at all the new technologies that are being offered one can see that new meta- skills are required by both students and lecturers. As new technologies in education emerge, the challenge is to remember why we are in the field of education - to teach people - a studentcentred approach should still remain. 
Figure 2. Meta-skills required in Distance Education as a result of new technologies

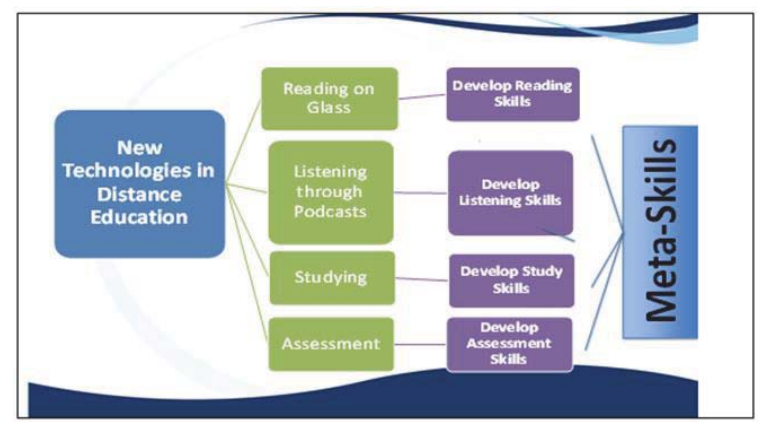

There are many new technologies emerging in distance education, and one of these is for example, the change from reading on print to reading on glass, whether it be on a tablet, a smartphone or computer screen.

Another technological development is the delivery of course content through podcasting which requires the development of listening and communication skills. New study techniques and new methods of online assessment require the introduction of meta-skills of time-management and various other skills.

Even though reading and writing will always be the backbone of distance education, available technologies such as pod-, pen- and video-casting have led to what is currently being called the "renaissance of the voice".

\section{Theoretical Framework}

Moore and Kearsley (1996) proposed the five generations of Distance Education. Figure 3 represents the five generations of the method of delivery of distance education, starting from the $1_{\text {st }}$ generation of delivery by means of print or the so-called correspondence method of distance education delivery. Thereafter various new technologies emerged, radio, film, television, computing and computer-assisted learning.

Figure 3. Five generations of distance education

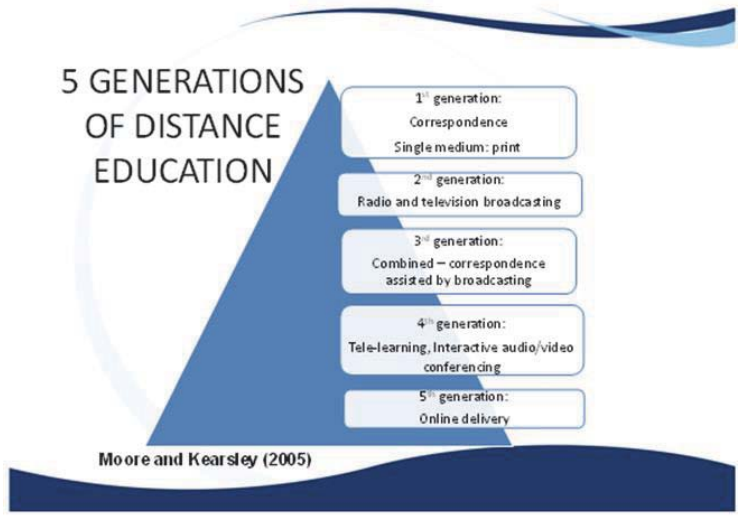

As can be seen from Figure 3, reading has always been at the forefront of teaching and learning and particularly in the case of Distance Education which has its very foundation on the so called $1_{\text {st }}$ generation of correspondence education.

Moore (2007) states that ODL is characterised by the distance that exists between educator, learner and institution, which he calls the transactional distance. He describes transactional as "the space where instructors and learners accomplish the work of learning in an environment that separates actors in both time and geographic distance", and also "the interplay of teachers and learners in environments that have the special characteristic of being spatially separate from one another". This situation creates a cognitive space between educator and learner, "a psychological and 
communications gap, a space of potential misunderstanding between the inputs of instructor and those of the learner".

In 1940, the motion picture was hailed as the most revolutionary instrument introduced into education since the printing press. This was followed by the use of TV and not long afterwards, it was the impact of computers. Also by the 1960 s the blending of technologies had created a rich communication environment.

The UK Open University was a leader in transforming Distance Education from a correspondence mode to multimedia distance learning. They started by using a range of media - mostly mass media - to enrich teaching and learning with e.g. TV and radio. They also used rapidly increasing developments in telecommunications to improve learner support. Then, as personal and social media enriched the mass media, the Open University followed this trend, retaining some elements of mass media while incorporating the mass media of the internet and the World Wide Web. Computer conferencing was incorporated into teaching systems (Daniel, 2013).

According to Bates (2005), instead of the Lone Ranger approach, which leaves eLearning up to individual academics and results in poor quality courses, institutions are now taking responsibility for the support that students need. Throughout the various generations of delivery method of distance education, one thing stands out clearly and that is the need for the development of communication skills whether it is through reading of printed material or reading on glass or listening to podcasts in the $4_{\text {th }}$ and $5_{\text {th }}$ generations of Distance Education delivery.

Another theoretical framework to look at is Anderson and Dron (2011) who describe three generations of distance education pedagogy, being cognitive-behaviourist, social- constructivist and connectivist. This is in contrast to the 5 generations discussed earlier which were based on the method of delivery and not the pedagogical assumptions.

Table 3. Theoretical Frameworks of Distance Education Pedagogy

\begin{tabular}{|c|c|c|c|c|c|c|c|}
\hline $\begin{array}{l}\text { Generation of Distance } \\
\text { Education Pedagogy }\end{array}$ & $\begin{array}{l}\text { Tech- } \\
\text { nology }\end{array}$ & \begin{tabular}{|l|} 
Learning \\
Activities
\end{tabular} & \begin{tabular}{|c|} 
Learner \\
Granularity
\end{tabular} & $\begin{array}{c}\text { Content } \\
\text { Gran-ularity }\end{array}$ & $\begin{array}{l}\text { Eval- } \\
\text { uation }\end{array}$ & $\begin{array}{l}\text { Teacher } \\
\text { Role }\end{array}$ & \begin{tabular}{|l} 
Scala- \\
bility
\end{tabular} \\
\hline Cognitive- behaviourism & \begin{tabular}{|c|} 
Mass media \\
Print \\
TV Radio \\
One-to one \\
commun-ication
\end{tabular} & $\begin{array}{l}\text { Read and } \\
\text { watch }\end{array}$ & Individ-ual & $\begin{array}{c}\text { Fine: } \\
\text { Scripted and } \\
\text { designed from the } \\
\text { ground up }\end{array}$ & Recall & $\begin{array}{l}\text { Content creator } \\
\text { Sage on stage }\end{array}$ & High \\
\hline Constructivism & $\begin{array}{c}\text { Conferencing } \\
\text { (Audio, video and } \\
\text { web) } \\
\text { Many-to-many } \\
\text { communication }\end{array}$ & $\begin{array}{l}\text { Discuss, } \\
\text { create and } \\
\text { construct }\end{array}$ & Group & $\begin{array}{c}\text { Medium: } \\
\text { Scaffolded and } \\
\text { arranged Teacher- } \\
\text { guided }\end{array}$ & $\begin{array}{l}\text { Synthe- } \\
\text { size: } \\
\text { Essays }\end{array}$ & $\begin{array}{l}\text { Discussion } \\
\text { leader Guide } \\
\text { on the side }\end{array}$ & Medium \\
\hline Connectivism & \begin{tabular}{|c|} 
Web 2.0 \\
Social networks \\
Aggregation and \\
recommender \\
systems
\end{tabular} & $\begin{array}{l}\text { Explore, } \\
\text { connect, } \\
\text { create and } \\
\text { evaluate }\end{array}$ & Network & $\begin{array}{l}\text { Course: Mainly at } \\
\text { object and course } \\
\text { level Self created }\end{array}$ & $\begin{array}{l}\text { Arte-fact } \\
\text { cre-ation }\end{array}$ & $\begin{array}{l}\text { Critical friend } \\
\text { Co-traveller }\end{array}$ & Low \\
\hline
\end{tabular}

Source: Anderson and Dron (2011)

From Table 3 it can be seen that the skills of reading and listening are required in each of the distance education pedagogies from TV, radio and one-to-one communication in the cognitive-behaviourist pedagogy, audio, video and web conferencing in the constructivist pedagogy to Web 2.0 and social connection in the connectivist pedagogy.

One way to empower students is to focus on learning strategies which can be defined as thoughts and behaviors intended to influence the learner's ability to select, acquire, organize, and integrate new knowledge (Weinstein \& Mayer, 1986). Learning strategies are designed to teach learners how to learn (Jonassen, 1985). Effective learning involves knowing when to use a specific strategy, how to access that particular strategy, as well as when to abandon an ineffective strategy (Fly-Jones, Sullivan-Palincsar, Sederburg-Olge \& Glynn-Carr, 1987). In 1986, McKeachie, Pintrich, Lin and Smith incorporated elements of several learning models, including the cognitive approach established by Weinstein and Mayer (1986), into a taxonomy of learning strategies. The taxonomy proposed by McKeachie et.al. encompasses the cognitive, metacognitive, and resource management aspects of learning (Table 2). 
Table 2. Taxonomy of Learning Strategies

\begin{tabular}{|l|l|}
\hline 1. Cognitive Strategies & Rehearsal strategies \\
\hline & Elaboration strategies \\
\hline 2. Metacognitive strategies & Organisational strategies \\
\hline & Planning strategies \\
\hline & Monitoring strategies \\
\hline 3. Resource management strategies & Regulating strategies \\
\hline & Time management \\
\hline & Study environment \\
\hline & Effort management \\
\hline & Support of others \\
\hline
\end{tabular}

(Adapted from Filcher \& Miller, 2000)

According to McKeachie et al. (1986) and Weinstein and Mayer (1986), cognitive strategies are important for understanding how information is processed and encoded in a learning environment, while metacognitive strategies allow a student to monitor his/her performance through planning, monitoring, and self-regulation. Resource management strategies assist the student in managing the learning environment and available resources (McKeachie et al., 1996). McKeachie et al.'s (1986) taxonomy is a clear, concise, and comprehensive model that identifies general learning strategies and specific learning tactics that may be examined in a Distance Education environment.

The cognitive component of McKeachie's taxonomy focuses on the methods by which students actively process information and structure this information into memory (Weinstein \& Mayer, 1986). In this regard, reading skills are examined in this article. Reading and comprehension skills are required in all three learning processes proposed by McKeatchie et al. (1996) i.e. cognitive strategies, which include rehearsal, elaboration, and organization, rehearsal strategies which are employed by learners to remember material using repetition (Olgren, 1998) and in elaboration by which the learner builds an internal connection between what is being learned and previous knowledge.

It is the contention of the authors that the poor quality of reading and comprehension skills, particularly in the South African context, is partly responsible for the low rate of academic success among Distance Education students.

Reading has always the backbone of ODL tuition, and it will always so. Students are often poor readers of printed material. However, there is a shift, even a revolution in the offing as we move through the generations of Distance Education. Reading is shifting from paper to glass. Are educators, students and institutions ready for this? Do we know what is coming?

For the purpose of this article, we have borrowed from both of these generational classifications. Technology plays a large part in communication in distance education. Unlike contact, classroom style content delivery, in Distance Education the method of content delivery is not through a face-to-face situation where lecturer and students can interact in close proximity with eye to eye contact. Content delivery has to be provided through a technological medium, which according to Moore and Kearsley (1996), can range from printed to audio to multimedia interactive communication.

Anderson and Dron (2011) state "It is clear that whether the learner is at the centre or part of a learning community or learning network, learning effectiveness can be greatly enhanced by applying, at a detailed level, an understanding of how people can learn more effectively: Cognitive, behaviourist, constructivist and connectivist theories each play an important role."

Ko and Rossen (2004) bring all of this together by stating that successful online learners need to possess the following skills

- Self-discipline

- Initiative

- Motivation

- Commitment

- Time-management

Flavell (1976) goes on to say that successful online learners display certain characteristics which include the metacognitive skills of planning, monitoring and evaluating yourself, your tasks and your strategies in the pursuit of meaningful goals. And these strategies, according to Coakley and Wolvin (1982) include listening, reading, writing and study skills. They go on further to state that the reality is that these skills are seldom taught continuously in higher education, with the meta-skill of listening being taught the least of all. 
There are many more examples of people writing about the need to develop these meta-skills, particularly in Distance Education. They are often referred to as the soft skills which are much neglected and yet so necessary for successful learning of students. For example the soft skills, as identified by the Conference Board of Canada (2003), that are required in the evolving work-force include:

- Good communication skills (reading/writing/speaking/listening)

- Social skills: ethics; positive attitudes; responsibility

- Team work

- An ability to adapt to changing circumstances.

NACOL (2006), the North American Council for Online Learning, states that "In an increasing competitive global economy, it is not enough for students to acquire subject-level mastery alone. Skills like creativity, problem solving, communication and analytical thinking are necessary for all levels of success ..."

Staudt (2001) in his keynote speech at the 20th ICDE World Conference on Open Learning and Distance Education, emphasizes the importance of two fundamental abilities that will be of importance in an informational-based society: the ability to ask the right question (good communication skills), and the ability to team resources and work cooperatively (team work and social skills).

Beetham and Sharpe (2013) state "The danger of business as usual with digital enhancements - when they are proven effective - is that we reproduce existing practices rather than appreciating where digital technologies have the potential to disrupt norms, challenge assumptions, innovate disciplines and professions, and usher in completely new forms of learning activity".

\section{Reading Abilities}

Good readers are good students. For millennia oral tuition was sufficient for informal tuition, but when writing and printing arrived on the scene, knowledge started to outlive the teacher, and an information explosion followed. Therefore people need to read in order to learn, especially in formal tuition (Pretorius 2002; Le Cordeur 2013).

In comparison with many countries, the reading proficiency of South African learners is low. The Progress in International Reading Literacy Study (PIRLS) report carried out in 2006 ranked South African grade 4 and 5 readers as the lowest out of 50 countries. The best readers came from the Russian Federation, Hong Kong (SAR) and Singapore (Mullis \& Martin 2007, Howie et al. 2008). Reading proficiency is the result of teaching reading in primary school, with reading at home and in pre-primary school also playing a crucial role. Schools where reading thrived had libraries and textbooks, were safe schools, did not have many children from disadvantaged backgrounds, and had teachers with a positive view of their teaching career.

The 2011 PIRLS report reported similar findings, with the following findings being reported about South African learners (Howie et al., 2012):

- South African Grade 4 learners, particularly those tested in African languages, achieved well below the international centre point despite having written an easier assessment. They were still performing at a low level overall on an easier assessment compared to their counterparts internationally.

- There was a significant gender gap in achievement, with Grade 4 girls outperforming boys in South Africa schools.

- Learners tested in Afrikaans and English performed relatively well and above the international centre point.

- However, those tested in all African languages, despite most writing in their home language, achieved very low outcomes, and learners tested in Sepedi and Tshivenda were especially low.

- Few South African learners (6\%) were able to read at an advanced level, although $71 \%$ were able to reach a rudimentary level of reading and attain the Low International benchmark.

- More than half the learners tested in Sepedi and Tshivenda could not read at a basic level required for successful reading.

The 2006 grade 5 students will begin to enroll at universities in 2014. Although reading tuition is supposed to be taught in South Africa as part of the school curriculum, the reality is that many schools do not attend to reading tuition satisfactorily. A clear indication of this is the fact that there was no improvement in reading proficiency between PIRLS 2006 and PIRLS 2011.

The implications for tertiary educations are important.

- Firstly, there will be a marked difference in reading abilities amongst students.

- Some will be excellent readers, but the majority will be average to poor readers.

- Secondly, a gender gap in reading is to be expected. 
- Thirdly, some students with mother tongue language other than English might be more at a disadvantage than English first language students.

Research confirms these expectations. According to Dreyer and Nel (2003), research conducted in South Africa indicates that many South African students who register for undergraduate study each year are under-prepared for university education and that many of these students also have low levels of reading ability.

If good readers make good students, then reading skills development should be very high on the agenda of tertiary institutions.

\section{Reading Explained}

Humans are born with neural networks dedicated to hearing and seeing. Babies in vitro can hear their mother's voice and other sounds, and apparently hearing is the last sense to linger when a person is dying. Humans start seeing from the moment they open their eyes, and are primed to see objects and their surroundings. It is a survival skill to make sense of objects and surroundings, being able to identify possible threats and to navigate terrain successfully. All of this developed over millennia, and are inborn human capacities.

Writing and reading developed only about 6000 years ago. In evolutionary terms it is way too short a time to become an inborn ability. Listening and seeing are inborn and therefore mastered without instruction, but reading has to be explicitly taught. To the eyes, writing symbols are merely objects and are seen as such. To recognise these symbols as representing speech and carrying meaning, the brain has to be changed and re-wired. Reading instruction therefore results in changing existing visual networks in a process called neuronal recycling. Existing networks are being changed and linked to other networks dedicated to language production, understanding and sounding (Dehaene, 2005; Dehaene, 2009; Wolf, 2007; Killian 2009, Buchweitz et al., 2009; Frey \& Frisher, 2010).

Neuronal pathways become established by repeated use. Early exposure to reading is therefore crucial where children are primed to identify the alphabetic objects and the medium carrying them (such as books) with audible spoken language conveying message and meaning.

Reading, however, is like fitness. If you are fit but then stop exercising, your fitness levels drop - and so does reading proficiency. Continued exposure and explicit teaching of reading is therefore important. When this is not done, learners lose some reading skills.

Reading begins with phoneme awareness, linking letters with speech sounds. Next to develop is the ability to decipher. Comprehension follows on from deciphering, if enough working memory is available. If reading proficiency is low, most of the working memory is devoted to deciphering, with little capacity left to focus on comprehension. Deciphering becomes automated in good readers, and this automaticity takes up little space in the working memory, leaving more for comprehension.

Lack of automaticity can be the result of certain neuronal networks not being in place. In such a case it is more a sense of pathology, needing specialised interference and therapy. Lack of automaticity may also be merely lack of exposure. In such a case focused tuition, training and modeling will make a positive difference.

Dedicated extra courses in reading may be a solution, and many institutions offer them. Poor readers enrolling at tertiary institutions, however, are already at a disadvantage. Because they read slowly and struggle with comprehension, they struggle to get through their work. Lack of progress and failure also impact on their self-esteem. Some students are willing to take a few steps back or tread water in order to progress better afterwards by taking extra skills classes. Many students, however, feel they do not have the time to do so, or that taking remedial classes are admittance that they are "failures", resulting in low motivation in starting or continuing remedial skills courses. Reading skills courses should therefore always be available, but more should be done. Making reading instruction part and parcel of course delivery and modeling good reading habits while teaching is necessary. This was impossible in the early days of Distance Education, where everything was done by correspondence and in writing. New technologies have opened new possibilities to teach and model reading, even at a distance.

The question is whether lecturers and administrators are aware of this and whether they make use of the opportunities offered by technologies. It is one challenge, however, to get poor readers to read proficiently on paper. Will that make them proficient readers on- screen? Is reading the same, irrespective of the medium? Is the bottled message merely written on paper and delivered by bottle, or does the bottle influence the message? Will they "get" the "message in the bottle"? 


\section{Reading on Paper and Reading on Screen}

All reading is the same, when the mechanism of reading is the issue. Letters or symbols leave an image on the fovea, the part of the retina that focuses sharply. From there impulses are sent to the occipital region, linking to the language areas, and the objects are interpreted as representing language carrying meaning.

All reading is not the same, however, when the media from which is being read is taken into account. The area where reading is computed and represented in the brain originally was used to see objects and navigate terrain. For this reason reading is still related to transversing a terrain, almost like visiting objects in context. A book is very similar to a terrain. It has a left and a right hand side, eight corners and depth. Paging is similar to walking, and readers often locate what they have read to a specific place and space on a page somewhere in the book.

A screen displays very few of these characteristics. The landscape orientation of a computer screen requires scrolling because part of the text does not fit on the screen. There is no tactile feel and feedback of how much has been read and how much is still left to be read as when you hold a book or magazine. Phone screens are even smaller, and scrolling more of a factor. Tablet screens can be rotated to mimic portrait orientation, but even so there is no real tactile feedback or orientation.

Much is being done to mimic physical paper books on screen. Web pages sometimes limit their length so that it can fit onto a screen, with buttons on the bottom indicating how many pages are left. Pdf documents mimic pagination and the exact same layout of the paper version. Some e-readers mimic the turning of pages and even the sound of turning a page as well as how many pages remain. E-Readers are screen-based and not page-based like pdf documents, but nonetheless give an indication of pagination such as "page 10 of 120". All of these are indications that books are still seen as the "industry standard" of reading.

The biggest difference between on paper reading and on screen reading is what is called "digital distraction". Paper books are fixed in what is being offered on the page, and because of that it is possible to immerse oneself into the book. With on-screen texts there is the possibility of endless links and extra information. It is therefore possible to click from link to link, and maybe never coming back to the starting point. Because it is so easy to open a link, drifting away from the original focus is a real threat. Reading might become very superficial.

Every reader knows, however, that reading on paper does not necessarily lead to immersion, deep understanding and creation of meaning. The challenges for creating meaning on paper is the fact that it is fixed, and might be boring, therefore also leading to becoming distracted. Conversely, on-screen readers sometimes do manage to read with success and understanding, without being distracted.

Poor readers will struggle with reading, irrespective of the medium. Proficient readers might read well, whether on paper or on screen.

What is necessary for reading is scaffolding and guiding strategies. Some strategies will be general to reading per se, while others need to be specific to the medium which is being used to read. Such guiding strategies are referred to as metacognitive reading strategies.

The medium from which it is read has an influence on the act of reading, and needs dedicated metacognitive guiding principles. Reading on paper needs strategies enabling focus in a mono-sensory input environment. Linear visual input has to suffice to create deep meaning and understanding, and the mind has to be guided to activate relevant meaning creating schemas. Reading on screen needs metacognitive guiding strategies to limit digital distraction of endless links. Stimulation of parallel multi-sensory inputs might lead to superficial reading and shallow understanding.

\section{The Meta-Cognition of Reading}

The Nike sports apparel range with the swoosh as its logo, has the slogan "Just do it!" Doing something is very important. However, even Nike would agree that in order to do something, you need to think about what you are doing, and that you need support structures to help you succeed in doing whatever you are doing. For Nike the latter part is their focus running is much easier and more effective if you sport the right apparel, shoes and gear. Professional sports people will also agree that the difference between winning and losing often lies in the sports person's mindset and the way she or he thinks.

This is not only true about sport. Every task we perform comprises these three aspects - doing it, thinking about doing it, and utilising enabling equipment, structures or strategies helping us doing it. In terms of reading, the "Just do it!" part is the reading itself.

As in sport, you get champions, average competitors and strugglers. When children are taught to read in primary school and become good readers, but then are just left without any further training and support, they do not retain their 
proficiency. Furthermore, reading is not just deciphering - much more is needed in order to read with understanding and comprehension. Good reading is also not merely about better reading strategies (Klopper, 2012). Klopper (2013) taught reading strategies to a group of grade 7 learners after a pre-test was done to measure their reading proficiency level. The post-test showed no improvement at all. Only after she taught the learners meta-cognitive awareness strategies to guide their reading strategies, their reading skills improved. This is even more important to students when they are reading academic or school related materials.

Skilled readers differ from unskilled or novice readers in the sense that they use deliberate reading strategies which they plan, monitor and evaluate as they read (Paris \& Jacobs 1984). They reflect on and monitor their thinking processes while reading and are aware of their reading strategies, choosing which to use when and knowing how to use them in order to comprehend what they are reading (Carrell 1991; Kern 1989, Shorey \& Mokhtari

2001; Song 1998, Mokhtari \& Sheorey 2002).

Students need to be made aware of and be trained to do this. In order to help students, and to measure the use of these strategies, Mokhtari and Reichard (2002) developed the MARSI test - the Metacognitive Awareness of Reading Strategies Inventory. It is a tool intended to measure native English speaking student's awareness and perceived use of reading strategies while reading academic or school-related materials (Mokhtari \& Sheorey, 2002). Mokhtari and Sheorey (2002) also developed the Survey of Reading Strategies (SORS). It is based on MARSI, but is intended for students for whom English is a second or foreign language (Mokhtari and Sheorey, 2002).

The inventory identifies the use of global reading strategies, problem solving strategies and support reading strategies. Global reading strategies refer to techniques used to monitor and manage reading, such as having purpose, planning and previewing. Problem solving reading strategies are actions and procedures that readers employ when reading, especially when readers experience problems. Support reading strategies refer to mechanisms used to support the reading process, such as using dictionaries, highlighting texts and note taking.

From this it is clear that reading is like any other task, consisting of doing, thinking about doing and being supported and assisted while doing. Reading is a task that needs training, and academic reading needs even more training. Students vary in levels of reading proficiency and have to be taught how to read - whether it is basic reading skills and strategies, medium-related strategies or subject related strategies. Stand-alone reading courses will always have a place, but the most natural way to teach reading is to model it in course content delivery.

\section{Teaching Reading Part and Parcel}

Reading instruction is afforded much attention in the early grades of school. During this time the focus is mainly upon the decoding of words. After this initial instruction, the teaching of reading is haphazard. Sometimes it is continued, but often it does not receive any further attention or formal instruction. What is mostly lacking is the teaching of reading comprehension strategies (Sonleitner 2005). Important reasons for this are that teachers do not feel qualified for teaching reading strategies and that they are not being trained sufficiently to provide reading instruction (Gillespie \& Rasinski, 1989; Shymansky, Yore \& Good, 1991; Yore, 1991; Sonleitner 2005). They also feel pressured to focus on content in order to cover the syllabus in the allotted time apart from the fact that they are not trained and supported to integrate reading instruction with teaching content (DiGisi \& Yore, 1992; Shymansky, Yore \& Good, 1991; Yore, 1991; Sonleitner, 2005; Howie et al., 2006).

Reading proficiency does not improve merely with age or by grade level, and the same is true of the use and awareness of metacognitive reading strategies (DiGisi \& Yore, 1992; Sonleitner, 2005). Without explicit instruction, readers will stay on their proficiency level or even slip backwards.

The move towards on-screen reading - or "bottled messages", has actually opened up a can of worms. The question of reading on screen has put the issue of reading in the spotlight again. It is clear that reading instruction should be given high priority starting in infancy. Reading instruction should continue throughout the school years and eventually into tertiary education, especially reading instruction for comprehension of academic texts. Central to this is the teaching of metacognitive reading skills, where learners learn to plan, monitor and evaluate their own reading strategies, becoming independent and skilled readers.

The rationale and need for teaching reading skills has been receiving much attention in academic publications, but has not changed much in teaching practice. What has also not received enough attention is the impact of these understandings on the role of academic staff. If teaching reading should be continuous and ongoing, accompanied by the fact that reading has subject specific qualities, then the people who should be teaching it are the subject specialists themselves. Having become a specialist in a field means they must have reached sufficient proficiency levels in reading the subject matter of their respective disciplines. However, just as being a specialist does not mean they are necessarily 
good teachers, being good readers of their discipline's subject matter do not make them good teachers of reading or good at modeling academic reading. Lecturers will have to become reading and reader specialists. They will have to be taught to teach reading to their students, and preferably taught to teach reading skills specific to their subject matter.

When teaching subject specific reading skills they will have to be knowledgeable about metacognitive and cognitive reading skills. They should also have to take into account the differences of skill levels of their students. Some students will be struggling readers. Some will be proficient readers on paper, but digital immigrants to reading on screen. Some will be digital natives used to reading on screen but maybe prone to distraction, and not used to reading on paper. Some might be seasoned citizens of the global village, at home on paper just as much as on screen - merely needing the reading skills to master the subject content. Reading skills needs to be taught as part and parcel of teaching subject content.

\section{Conclusion and Further Research}

More and more academic messages and texts have to be read on screen. Students need to be trained to read. Lecturers need to be trained to teach reading. This article needs to be followed up by research in specific disciplines and subjects, to measure students' metacognitive reading skills, their reading proficiency and how reading can be taught. Research should also be carried out on lecturers' knowledge of the required reading skills, linked to medium, subject, student profile and pedagogy of teaching reading. In short, students and lecturers should be taught how to READ:

- Recognise - and decipher;

- Ecologise - be sensitive to the peculiarities of differing modes of delivery such as paper and on screen;

- Accompany - guide the reading process with relevant strategies; and

- Deeply understand - make sense and meaning of the message, fitting it into the reader's world.

The way our academic messages are being bottled, will have a huge impact on whether the recipients will be able to open them. It is best we attach the bottle opener to the bottle to make sure it can be read properly.

\section{Bibliography}

Anderson, T. and Dron, J. (2011). Three generations of distance education pedagogy. International review of research in open and distance learning. Vol 12(3), 80-97.

Bates, T. (2005). Technology, e-learning and Distance Education. New York: Routledge.

Beetham, H. and Sharpe, R. (2013). Rethinking pedagogy for a digital age. New York: Routledge.

Buchweitz, A., Mason, R.A., Tomitch, L.M.B. and Just, M.A. (2009). Brain activation for reading and listening comprehension: an fMRI study of modality effects and individual differences in language comprehension. Psychology and Neuroscience 2111-123

Carrell, P. L. (1991). Second language reading: Reading ability or language proficiency? Applied Linguistics, 12(2), 159-179.

Coakley, C. and Wolvin, A. (1997). Listening in the educational environment. In: M.Purdy and D. Borisoff (Eds.) Listening in everyday life: A personal and professional approach (2nd ed.) (pp. 179-212). 1982. Lanham, MD: University Press of America. Conaway.

Conference Board of Canada. (2003). Leading employment solutions firm launches innovative solution to Canada's skill shortage. http://www.conferenceboard.ca/press/2003/innovative_solution.asp. Accessed 12 July 2013.

Daniel, J. (2013). Education across space and time. Keynote address ODLAA summit on 4

February 2013. www.odlaasummit.org.au/keynote-speakers.php. Accessed 12 July 2013.

Dehaene, S. (2005). Evolution of human cortical circuits for reading and arithmetic: The "neuronal recycling" hypothesis. In S. Dehaene, J. R. Duhamel, M. Hauser \& G. Rizzolatti (Eds.) 2005, From monkey brain to human brain. Cambridge, Massachusetts: MIT Press.

Dehaene, S. (2009). Reading in the brain: the new science of how we read. New York: Penguin.

DiGisi, L. L. \& Yore, L. D. (1992) Reading comprehension and metacognition in science: Status, potential, and future direction. Paper presented at the Annual Meeting of the National Association for Research in Science Teaching, Boston, MA.

Dreyer, C. and Nel, C. (2003). Teaching reading strategies and reading comprehension within a technology-enhanced learning environment. System 31, $349-365$.

Education for Change. (2012). Researchers of Tomorrow. The research behaviour of Genertion Y doctoral students. JISC and British Library, http://www.jisc.ac.uk/publications/reports/2012/researchers-of-tomorrow.aspx\#menu.

Flavell, J. H. (1976). Metacognitive aspects of problem solving. In L. B. Resnick (Ed.), The nature of intelligence (pp.231-236). Hillsdale, $\mathrm{NJ}$ : Erlbaum.

Filcher, C. and Miller, G. (2000). Learning strategies for distance educarion students. Journal of agricultural education. Vol.41(1), 62-68.

Frey, N. and Fisher, D. (2010). Reading and the brain: what early childhood educators need to know. Early childhood Education Journal 38: 103-110.

Gillespie, C., \& Rasinski, T. (1989). Content area teachers' attitudes and practices toward teaching reading in the content areas: A review. Reading Research and Instruction, 28, 45-67. 
Howie, S., Venter, E., Van Staden, S., Zimmerman, L., Long, C., Du Toit, C., Scherman, V. and Archer, E. (2008). PIRLS 2011. South African Children's reading literacy achievement. Summary Report. Centre for Evaluation and Assessment, University of Pretoria.

Howie, S., Van Staden, S., Tshele, M., Dowse, C. and Zimmerman, L. (2012). PIRLS 2011. South African Children's reading literacy achievement. Summary Report. Centre for Evaluation and Assessment, University of Pretoria.

Jabr, F. (2013). The reading brain in the digital age: the science of paper versus screens.

Scientific American Thursday April 11, 2013: 24 (http://www.scientificamerican.com/article.cfm?id=reading-paper-screens)

Jonassen, D. H. (1985). Learning strategies: A new educational technology. Programmed

Learning and Educational Technology, 22(1), 26-34.

Fly-Jones, B., Sullivan-Palincsar, A., Sederburg-Ogle, D., \& Glynn-Carr, E. (1987). Strategic teaching and learning: Cognitive instruction in the content areas. Virginia: Alexandria.

Kern, R. G. (1989). Second language reading strategy instruction: Its effects on comprehension and word inference ability. The Modern Language Journal, 73(2), 135-149.

Killian, L. (2009). New textual formats: reading online is re-wiring the human brain and changing how we process information. Dalhousie Journal of Interdisciplinary Management 4, 2 - 11.

Klopper, B. (2012). Riglyne vir die effektiewe onderrig van leesbegripstrategieë in die Seniorfase. Ongepubliseerde M.Ed-proefskrif, Kaapse Skiereiland Universiteit van Tegnologie, Wellington.

Klopper, B. (2013). Metakognitiewe bewustheid as vereiste vir die effedtiewe onderrig van leesbegripstrategieë. LitNet Akademies 10, 2. Ko, S. and Rossen, S. (2004). Teaching online: a practical guide. Boston: Houghton Mifflin Company.

Le Cordeur, M. (2013). Teaching reading across the curriculum in secondary schools, in Wood, L. and Wolhuter, C.C. 2013. Criticality, creativity and connections: in pursuit of educational innovations. Proceedings of the 2012 Annual Conference of EASA Education Association of South Africa 17-20 January 2012. Platinum: Potchefstroom.

McKeachie, W. J., Pintrich, P.R., Lin, Y. and Smith, D. (1986). Teaching and learning in the college classroom: A review of the research literature. Ann Arbor, MI: National Center for Research to Improve Postsecondary Teaching and Learning, University of Michigan.

Mokhtari, K. and Sheorey, R. (2002). Measuring ESL students' awareness of reading strategies. Journal of Developmental Education p2 $-20$.

Mokhtari, K., \& Reichard, C. A. (2002). Assessing students' metacognitive awareness of reading strategies. Journal of educational psychology, 94(2), 249.

Moore, M. G. 1997. Theory of Transactional Distance. In D. Keegan (Ed.) In: Theoretical

Principles of Distance Education. (1997). Abingdon: Routledge

Moore, M. G. and Kearsley, G. (1996). Distance education: A systems view. Washington: Wadsworth Publishing Company.

Moore, M. G. Kearsley.(2005). Distance education: A systems view. Belmont, CA: Thomson/Wadsworth.

Moore, M. G. (2007). Handbook of distance education. New York: Routledge.

Mullis, I.V.S. and Martin, M.O. (2007). Overview of PIRLS 2006 results. TIMSS \& PIRLS International Study Center, Lynch School of Education, Boston College, USA.

North American Council for Online Learning (NACOL). (2006). http://www.p21.org/events- aamp-news/press-releases/280-onlinelearning-and-virtual-schools-provide-essential-new-skills-for-21st-century-jobs-says-report. Accessed on 10 July 2013.

Olgren, C. H. (1998). Improving learning outcomes: the effects of learning strategies and motivation. In C. Campbell Gibson (Ed.)., Distance learners in higher education: Institutional response for qualitative outcomes (pp. 77-96). Madison, WI: Atwood Publishing.

Paris, S. G., \& Jacobs, J. E. (1984). The benefits of informed instruction for children's reading awareness and comprehension skills. Child development, 2083-2093.

Pretorius, E. J. (2002). Reading ability and academic performance in South Africa: Are we fiddling while Rome is burning?

Sheorey, R. A., \& Mokhtari, K. (2001). Differences in the metacognitive awareness of reading strategies among native and non-native readers. System, 29(4), 431-449.

Shymansky, J.A., Yore, L.D., \& Good, R. (1991). Elementary school teachers' beliefs about and perceptions of elementary school sciences, science reading, science textbooks, and supportive instructional factors. Journal of Research in Science Teaching, 28, 431-454.

Song, M. J. (1998). Teaching reading strategies in an ongoing EFL university reading classroom. Asian Journal of English Language Teaching, 8(1), 41-54.

Sonleitner, C. L. (2005). Metacognitive strategy use and its effect on college biology students' attitude. Toward reading in the content area. Unpublished MSc Thesis: Graduate College of the Oklahoma State University.

Staudt, E. (2001). Keynote address 20th ICDE world conference. The future of learning, learning for the future: shaping the transition. Plenary session 2, Dusseldorf, Germany.

Weinstein, C. E. and Mayer, R. E. (1986). The teaching of learning strategies. In M.Wittrock (Ed.), Handbook of research on teaching. (pp. 315-327). New York: Macmillan.

Wolf, M. (2007). Proust and the squid: The story and science of the reading brain. New York: HarperCollins.

Yore, L.D. (1991). Secondary science teachers' attitudes toward and beliefs about science reading and science textbooks. Journal of Research in Science Teaching, 28, 55-72.

Yore, L. D., Bisanz, G.L. \& Hand, B.M. (2003). Examining the literacy component of science literacy: 25 years of language arts and science research. International Journal of Science Education, 25(6), 689-725. 